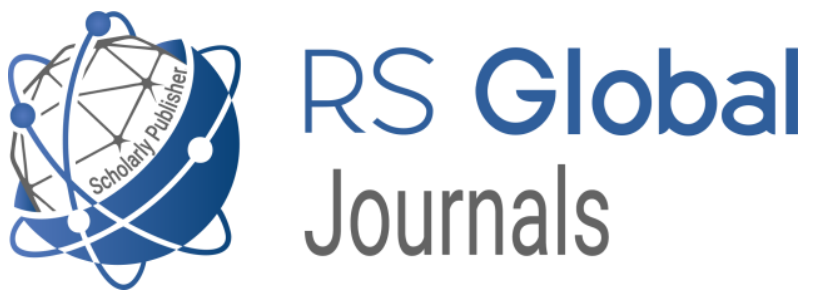

Scholarly Publisher RS Global Sp. z O.O. ISNI: 0000000484952390

Dolna 17, Warsaw, Poland 00-773

Tel: +48226022703

Email: editorial_office@rsglobal.pl

\begin{tabular}{ll} 
JOURNAL & Science Review \\
\hline p-ISSN & $2544-9346$ \\
\hline e-ISSN & $2544-9443$ \\
\hline PUBLISHER & RS Global Sp. z O.O., Poland
\end{tabular}
$\begin{array}{ll}\text { ARTICLE TITLE } & \text { POTENTIAL WITHIN AVIATION TRANSPORT LAND } \\ \text { MANAGEMENT DEVELOPMENT }\end{array}$

AUTHOR(S) Iryna Novakovska, Igor Slavin,

Nataliia Ishchenko, Liliia Skrypnyk

Iryna Novakovska, Igor Slavin, Nataliia Ishchenko, Liliia

Skrypnyk. (2020) Peculiarities of Alternative Fuel and Power

ARTICLE INFO Potential within Aviation Transport Land Management

Development. Science Review. 7(34).

doi: 10.31435/rsglobal_sr/31102020/7219

DOI

https://doi.org/10.31435/rsglobal_sr/31102020/7219

RECEIVED

20 August 2020

ACCEPTED

08 October 2020

PUBLISHED

13 October 2020

LICENSE

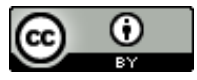

This work is licensed under a Creative Commons Attribution

4.0 International License.

(C) The author(s) 2020. This publication is an open access article. 


\title{
PECULIARITIES OF ALTERNATIVE FUEL AND POWER POTENTIAL WITHIN AVIATION TRANSPORT LAND MANAGEMENT DEVELOPMENT
}

\author{
Iryna Novakovska, Doctor of Economics, Associate Professor, Head of the Department of Aerospace \\ Geodesy and Land Management, National Aviation University, Kyiv, Ukraine, \\ ORCID ID: https://orcid.org/0000-0002-1473-7543 \\ Igor Slavin, PhD (Tech.), Associate Professor of the Department of Aerospace Geodesy and Land \\ Management, National Aviation University, Kyiv, Ukraine, \\ ORCID ID: https://orcid.org/0000-0003-1198-292X \\ Nataliia Ishchenko, PhD (Economics), Associate Professor of the Department of Aerospace Geodesy \\ and Land Management, National Aviation University, Kyiv, Ukraine, \\ ORCID ID: https://orcid.org/0000-0002-3745-9742 \\ Liliia Skrypnyk, PhD (Economics), Senior Lecturer of the Department of Aerospace Geodesy and \\ Land Management, National Aviation University, Kyiv, Ukraine, \\ ORCID ID: https://orcid.org/0000-0001-7349-9496
}

DOI: https://doi.org/10.31435/rsglobal_sr/31102020/7219

ARTICLE INFO

Received 20 August 2020

Accepted 08 October 2020

Published 13 October 2020

\section{KEYWORDS}

land management, aviation transport, alternative fuel, power, potential, resources, energy.

\begin{abstract}
The article analyses peculiarities and specific features of the use of alternative power and fuel capacities during its formation in the sphere of air transport land management. The following elements of the system for producing powerefficient resources comprises have been considered. It substantiates the necessity to involve the concepts of design and use of a modern power-efficient airport infrastructure and its connection with sound and efficient land management. The authors consider the experience of other countries and the perspectives of alternative power and fuel resources - the "green areas". Also It have been established that every new project of an airport or a reconstructed one, shall be focused on meeting the latest standards of minimization of the airport's impact on the environment and on the reduction of climatic changes, connected with its infrastructure and activities. Within the studies of the experts in the sphere of the aviation industry, and the members of ICAO council, it have been considered the concept of development and use of a modern, powerefficient airport infrastructure. The authors have proposed a modification of the methodological calculation of resource conservation indicators by reducing fossil fuel emissions within the airport and surrounding areas.
\end{abstract}

Citation: Iryna Novakovska, Igor Slavin, Nataliia Ishchenko, Liliia Skrypnyk. (2020) Peculiarities of Alternative Fuel and Power Potential within Aviation Transport Land Management Development. Science Review.7(34).doi: 10.31435/rsglobal_sr/31102020/7219

Copyright: (C) 2020 Iryna Novakovska, Igor Slavin, Nataliia Ishchenko, Liliia Skrypnyk. This is an openaccess article distributed under the terms of the Creative Commons Attribution License (CC BY). The use, distribution or reproduction in other forums is permitted, provided the original author(s) or licensor are credited and that the original publication in this journal is cited, in accordance with accepted academic practice. No use, distribution or reproduction is permitted which does not comply with these terms.

Introduction. To achieve the proper functioning of the aviation industry, nature-friendly land management, the compliance of an airport infrastructure with the adjacent territories, we have to consider a reasonable plan of an airport. For instance, establish maximum allowable levels for contaminating substances, and plan the land management for adjacent territories out of the borders of the entity. The main task in land management prognostication and planning is to ensure the best possible inner conditions safe for nature, communities of suburbs, and ecology of the environment. 
One of the essential elements of this system to function is ecological certification, which means implementation and control over natural-friendly equipment, and, consequently, environmentalsafe processes. It also stipulates the stable manufacturing of natural-friendly products. This procedure requires meeting modern trends, rules, and regulations while building of an airport. Special technical equipment, machinery, buildings, and constructions, among them - terminals and warehouses for fuel and oil materials shall also meet the said requirements. (Figure. 1).

Hence, within the up-to-date conditions of aviation industry development, the processes of improving the use of alternative power and fuel for efficient decisions on making the environment inside and outside the airport more environmentally friendly play now a viable role. The system for producing power-efficient resources comprises of the following elements:

Manufacturing and use of the technology and equipment to control and reduce emissions of hazardous substances and greenhouse gases;

Preserving and developing green plant areas on the territory of an airport and out of it;

Monitoring and predicting changes in nature and climate;

Implementing technological processes aimed at saving power and resources, renewable energy [11].

Results. The first stage of planning and designing of an airport starts from revealing limitations and establishing priorities for the future object. To get the information required, we need an economical and ecological assessment to determine expected passenger flows, demands of renters and concessions, specific requirements to the object's design or reconstruction.

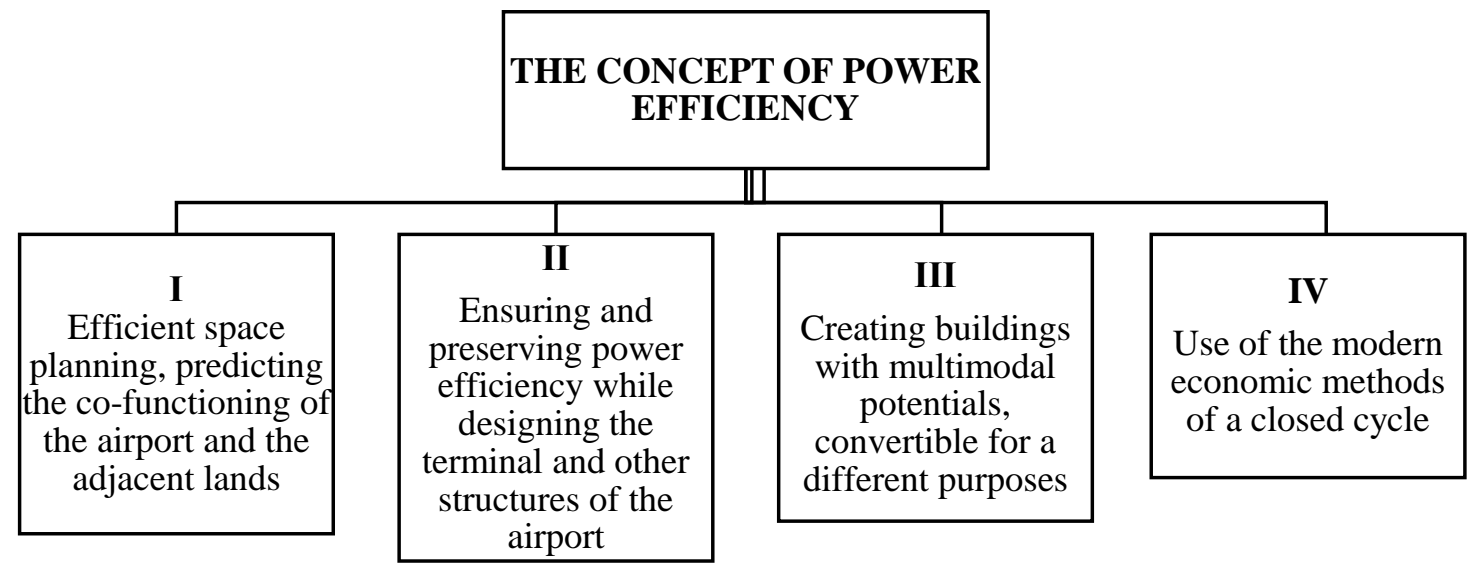

Fig. 1. The basic elements of the concept for design and use of a modern, power-efficient airport infrastructure [6]

A terminal is the biggest and the most complex unit of an airport. As a rule, it has the largest power consumer. First, the experts in planning and design of airport shall determine a range of natural consequences the object will have in use, for further including into a budget. It is worth to mention that a new infrastructure demands an assessment of its impact on the environment of some similar land areas.

In turn, an efficient space planning of a future terminal is a prerequisite for:

- Reducing distances between the districts;

- Including a new element of transport infrastructure to facilitate the flow of passengers and their multimodal access;

- Minimization of the distance for a dedicated transport from the gates or parking to the runways and turn-off strips;

- Reducing the fuel consumption and hazardous substances emission while the ground taxiing of aircraft;

- Minimization of the effect of noise of the surrounding lands and communities;

- Minimization of fuel consumption and energy expenditures on the vehicles rented due to the tight schedule for the airport [5].

Thus, to choose a land plot for such a unit as a terminal, one should consider reasonable intermodal transportation with the smallest possible power consumption specific elements typical of it as a destination.

Designing a layout of units where the large groups congregate shall focus on the use of alternative types of power resources in form of natural light and ventilation. All methods, minimizing 
the expenditures of power required for heating, cooling, and lighting of the construction shall make it more efficient and resistant to different impact-factors from a long-term perspective.

In modern conditions of development, large-scale airports get often changed rather quickly, so some of the airports designed nowadays stipulate the building with potential multimodal capacities, convertible for a purpose, different from an initial one. It means that in the process of design and planning, it is expedient to create an infrastructure available for a re-equipment for different purposes in the future [1].

Power production leads quite often to the emission of hazardous substances and significant energy consumption. Thus, power efficiency must always be a priority task in reconstructing terminals, considering economical and ecological factors.

Power efficiency includes the following factors:

- Insulation and low-consuming equipment, and special design of premises, considering requirements to ventilation;

- Designing of a "green roof", able to reduce the thermal absorption, thus decreasing power consumption, drainage of rain waters, and serve as noise suppression structure along the runway;

- The use of renewable power sources like wind, sun, water power stations and other technologies, probably integrated in the future into construction with a different purpose [12].

For instance, some projects of airports apply a method of a solar wall, which is an external wall of a terminal, used for heating water than circulating throughout the building. Some airports have their own "micro-network" or a system for producing power at airports. An airport, generating its capacity, especially at the account of the renewable methods, increases its resistance against the external influences.

Quite interesting are trends to use the modern computer-aided technologies for automated management of systems of the whole buildings, making the airport operators able to control the system's conditions without focusing on specific power-consuming elements. These technologies ensure automatic tracing of power consumption and corrective actions, for instance, to change air temperature or regulate the light, if required.

Our research of the world's modern airport infrastructure have been shown that despite all the latest advances in efficient energy management and resource conservation in the transport use, including aviation, $70 \%$ of airlines use a traditional energy system. That is why modern aviatuin system requires effective project development to modernize outdated infrastructure, the introduction of new technologies for the use of alternative energy solutions, as well as significant capital investment, which for some countries is currently impossible. For reducing the consumption of fossil fuels, conserve natural resources and eliminate emissions of harmful residues that they generate, we propose to use a general scheme for calculating carbon dioxide emissions, which includes a number of interrelated components of the airport structure (Figure.2)

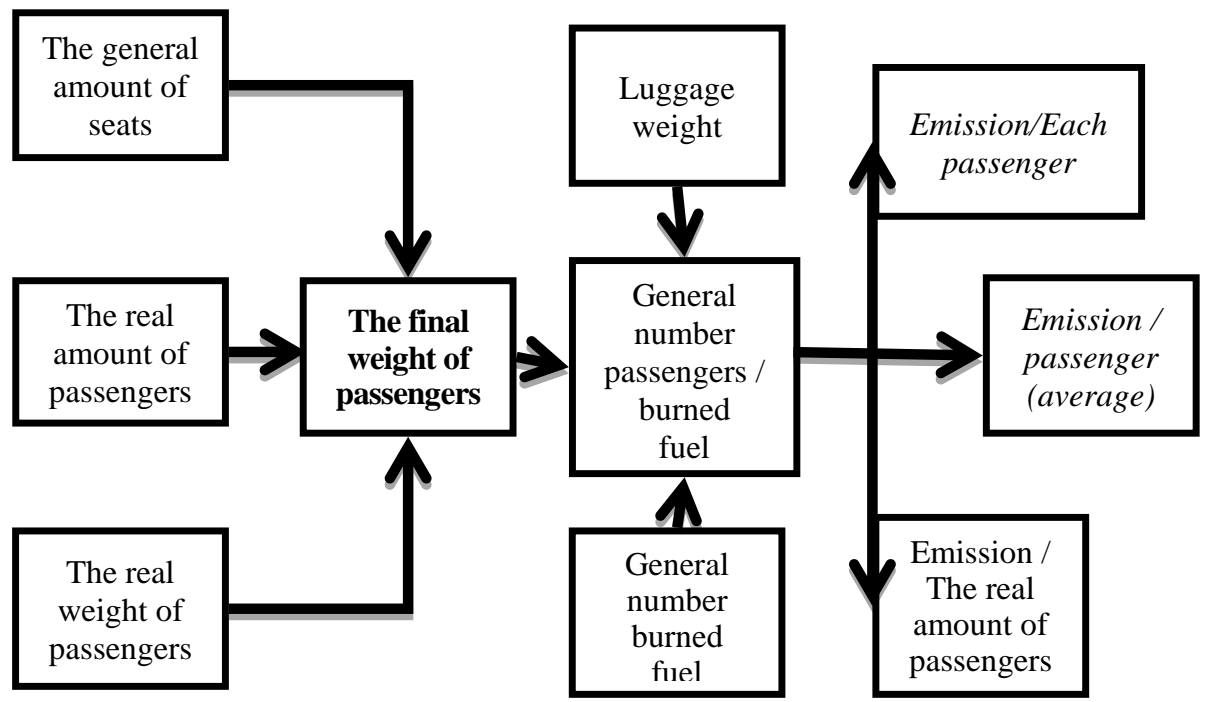

Fig. 2. The relationship of the components of the system, which is used in the methodological calculation of resource conservation by reducing fossil fuel emissions

* Formed by the authors 
Components used in the methodological calculation of resource conservation by reducing fossil fuel emissions: passenger.

1. Number of seats - determination the load factor required to calculate the emission per

2. Number of transported passengers - obtaining the load factor.

3. The amount of fuel used - obtaining the load factor.

4. Passenger weight - using the standard value of $100 \mathrm{~kg}$ and in accordance with ICAO requirements, add $50 \mathrm{~kg}$ per seat.

5. Cargo weight (capacity) - distribution fuel consumption between passengers and cargo, which is placed in the cabin and a special cargo compartment. separately.

6. Road class - the calculation of emissions when traveling economy class and premium class

According to the latter materials, emissions are doubled [11]:

$$
\mathrm{G}_{\mathrm{Pn}}=\mathrm{S}_{\text {pit.mg }} \mathrm{R}_{\mathrm{mg}} \mathrm{T}_{\mathrm{mg}}
$$

where $S_{\text {pit.mg }}$ - specific fuel consumption during engine operation at low gas, $\mathrm{kg} / \mathrm{h}$;

$\mathrm{R}_{\mathrm{mg}}$ - thrust of the engine in low gas mode (given in the engine form as its technical characteristics), $\mathrm{H}$;

$\mathrm{T}_{\mathrm{mg}}$ - engine operating time in low gas mode for one take-off and landing cycle, $\mathrm{h}$.

In order to save energy resources as a result of our own research, we propose to calculate the rate of energy exchange and unburned fuel residues during operation of the aircraft engine, as well as their penetration zone per flight cycle (LTO) by the following formula [11]:

$$
\mathrm{IFC}=[\Sigma(\mathrm{N}) \mathrm{FCi} / \mathrm{LTO}] / \mathrm{A}
$$

where $\mathrm{N}-$ the number of flight cycles;

LTO - calculated for a certain period of time;

FCi / LTO - the number of unburned fuel residues during the operation of the aircraft engine, as well as their penetration zone (tons / LTO-cycle / year);

A - land area.

While projecting an airport, important is to use economical closed-cycle methods or a cyclic economy based on a concept of renewable resources. It is an alternative to a linear economy and ensures an integrated approach to elaborating new economy business models (e.g. foodstuff servicing systems), where the cost of the assets (e.g. buildings of terminals) and the services are preserved as high as possible. The cyclic economy includes all stages of terminal development (designing, building, and use). The buildings of terminals must have a design suitable for reuse, dismantling, reconstruction, or recycling. Airport operators shall strive to minimize the use of not recycled materials.

Discussion. Implementation of technological processes relating to saving power and resources and renewable energy is a precondition for making efficient decisions on greening the environment on the territory of an airport and out of its borders by creating the "green areas" [11]. (Figure.3.).

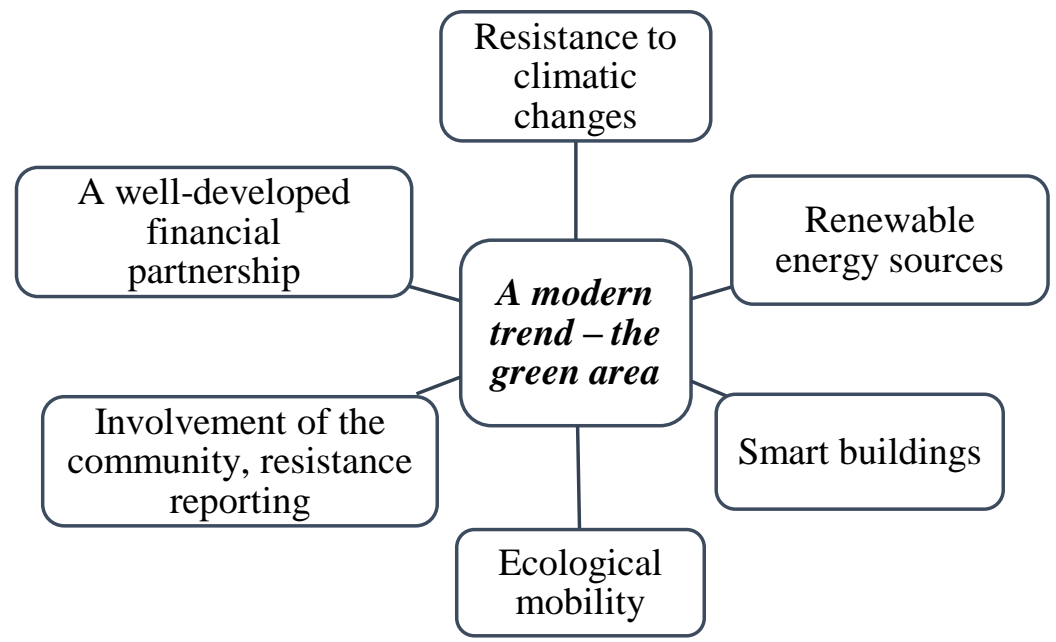

Fig. 3. Structural elements of a "green area" system [5] 
Every project of an airport - a new or a reconstructed one, shall be focused on meeting the latest standards of minimization of the airport's impact on the environment and on the reduction of climatic changes, connected with its infrastructure and activities. By proposition of the International Civil Aviation Association (ICAO), the leading states in the sphere of aviation industry shall share ideas of the latest technological, economical, environmental, and political achievements aimed at helping the airports worldwide in their constant combat for reducing the emissions of greenhouse gases and ensuring more stable operation (Figure.4).

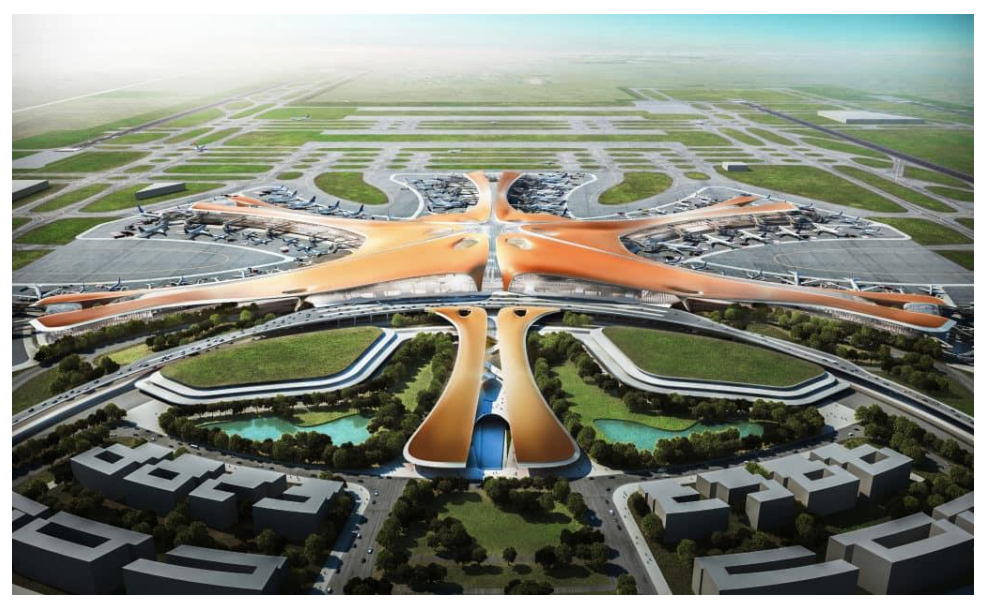

Fig. 4. The project of an airport with an environmentally well-developed and energetically stable "green area" infrastructure [5]

According to the conferences being held, the Council of ICAO has emphasized the following ideas (Table 1):

- Efficient management of consequences of airport operations for the environment;

- The use of a certification scheme for operators;

- Specific features of installing sun and wing power stations, power resources of biomass, and energy of a tidal influx;

- Initiatives on stable mobility;

- Adaptation and resistance to climate changes;

- Active public participation;

- Financing of environmental projects and current expectations of investors;

- Monitoring of stable development.

Table 1. The experience of foreign countries in the use of alternative power resources [9]

\begin{tabular}{|l|l|l|}
\hline \multicolumn{1}{|c|}{ № } & \multicolumn{1}{|c|}{ Name of an airport } & \multicolumn{1}{c|}{ Alternative fuel and power resources } \\
\hline 1. & $\begin{array}{l}\text { Seymour international } \\
\text { airport (Galapagos islands) }\end{array}$ & $\begin{array}{l}\text { Exclusively renewable power sources - sun and wind power } \\
\text { plants }\end{array}$ \\
\hline 2. & $\begin{array}{l}\text { Incheon international } \\
\text { airport (SouthKorea) }\end{array}$ & $\begin{array}{l}\text { The newest power-saving technologies, optimization of the } \\
\text { natural ventilation, lighting, large-scale photo-elements } \\
\text { installed }\end{array}$ \\
\hline 3. & $\begin{array}{l}\text { Hanimadhoo Airport } \\
\text { (Maldives) }\end{array}$ & $\begin{array}{l}\text { Implementation of highly efficient decisions on the use of } \\
\text { water, sun, and wind power plants }\end{array}$ \\
\hline 4. & $\begin{array}{l}\text { Edmonton international } \\
\text { airport (Canada) }\end{array}$ & $\begin{array}{l}\text { Alive installation, designed in the form of a vertical green } \\
\text { garden on a wall; it has 430 square meters of area and over } \\
\text { 32 species of plants }\end{array}$ \\
\hline 5. & $\begin{array}{l}\text { East Midlands Airport } \\
\text { (England) }\end{array}$ & $\begin{array}{l}\text { The use of windmills, underground water sources for } \\
\text { producing electricity; a water-purification system to reduce } \\
\text { the negative emissions into the environment }\end{array}$ \\
\hline 7. & $\begin{array}{l}\text { Logan International } \\
\text { Airport (USA) }\end{array}$ & $\begin{array}{l}\text { Power-saving lighting, the roof made of a membrane filter } \\
\text { water for technical purposes }\end{array}$ \\
\hline Denver International & $\begin{array}{l}\text { Sun energy applied for heating and feeding the hardware; a } \\
\text { taxi-park, equipped with electric vehicles; its territory hosts } \\
\text { one of the greenest parking places of the world }\end{array}$ \\
\hline
\end{tabular}


It should be emphasized that while elaborating a brand-new airport infrastructure, involving a "green area", the special attention must be paid on the specific features of power management of vehicles for the access from a city or seaside to the airport, the access from the airport to the aircraft. Respectively, an elaboration to the access ways or transport availability shall include material and technical support, ground servicing and use, as well as the production of environmentally resistant alternative types of fuel or power [10].

The use of fuel and energy resources with a low level of emissions to the atmosphere shall include electrification (the use of electric vehicles for transportation, collection of the power and wastes, distribution of pure energy), or a stable alternative fuel (an improved bio-fuel, green hydrogen, ammonia), implementation of innovative digital decisions, including the new instruments and mechanisms for implementation of the innovative digital solutions, including the new tools and mechanism to optimize the traffic for multimodal access to the passenger and cargo flows.

Conclusions. The proposed modification of the methodological calculation of resource conservation by reducing fossil fuel emissions within the airport and surrounding areas is a guarantee of protection of the environment and surrounding areas, reducing consumption and consumption of fossil fuels, conservation of natural resources and elimination of harmful residues. a solution for the conservation of natural resources and the transition to the use of alternative fuels in the land use of air transport. According to the studies of the experts in the sphere of the aviation industry, and the members of ICAO council, the concept of development and use of a modern, power-efficient airport infrastructure is intended to ensure:

Removal of emissions of the dangerous substances connected to the use of the airports till 2030;

Improving the quality of air, preserving biological diversity;

The use of cyclic economic methods;

Reducing noise at airports;

Power-saving operations of airport buildings;

Development of eco-logistics;

Integration with the different types of transport with a low level of emissions of the hazardous residuals after burning the fuel;

Reduction of emissions for towns and cities, and urban mobility, improved integration between the cities and the airports;

Clear obligations and contributions into the pan-European implementation of innovative decisions within and out of the margins of the projects are expected as further actions, for instance, within the support from the Fund of European Connection or other financial programs.

\section{REFERENCES}

1. Airport environmental noise mapping and land use management as an environmental protection action policy tool: The case of the Larnaka International Airport. Science of the Total Environment, 162-173 pp. Available at: https://www.academia.edu/38758445/Airport_Environmental_Noise_Mapping_and_Land_Us e_Management_as_an_Environmental_Protection._The_Case_of_the_Adisucipto_International_Airport_Y ogyakarta_Indonesia (Accessed: 05 September 2020).

2. Airport planning standards (New York, New Jersey) (2018). Available at: https://www.panynj.gov/business-opportunities/pdf/panynj-terminal-planning-guidelines.pdf (Accessed: 05 September 2020).

3. A consultative circular FAA 150 / 5360-13A, Planning a terminal of an airport Akyüz et al (2017).

4. Economical and ecological optimization of making walls and a roof of an airport terminal coldproof. 9 (10), 1849.

5. Green thinking, Greener Airports (ICAO) (2018). Available at: https://unitingaviation.com/news/environment/green-thinking-greener-airports/

6. Green airports and ports as hubs for sustainable and smart mobility (2020). Available at: https://ec.europa.eu/info/sites/info/files/research_and_innovation/green_deal/gdc_stakeholder_engagement _topic_05-1_green_airports_and_ports.pdf

7. Horonjeff R., McKelvey F. (1994). Planning and design of airports, 4th ed. New York, NY: Mc Graw-Hill.

8. Novakovska I.O., Skrypnyk L.R. Research Affect ECOLOGICAL-ECONOMIC FACTORS ON LAND USE OF AVIATION TRANSPORT. International Journal of Innovative Technologies in Economy, Poland, 2019 3(23), 14-21. https://doi.org/10.31435/rsglobal_ijite/30042019/6451 
9. Novakovska, N. Belousova, N. Ishchenko, L. Skrypnyk, V. Frolov. Aviation Industry of XXI Century: Development and Necessity or Serious Threats for Natural Ecosystems / Selected Aspects of Providing the Chemmotological Reliability of the Engineering/ Ed. by S. Boichenko, O. Aksionov, P. Topilnytskyi, A. Pushak, K. Lejda. Center for Educational Literature. Kyiv. Paris. 2019. Chapter 3. P. 226-238 DOI: doi.org/10.18372/38229

10. Ortega Alba et al (2016). Energy studies at the airports: a review. Energies. 9(5), 349. https://unitingaviation.com/news/environment/green-thinking-greener-airports/

11. Skrypnyk L.R. Ekologobezpechne vykorystannia zemel aviatsijnogo transport [The Naturally-safe Land Management in Aviation Transport] in Ukrainian. A PhD thesis, speciality 051 - Economics. - 2020. - 287 pages.

12. The Eco-Design of Airport Buildings. ICAO. Environment (2019). Available at: https://www.icao.int/environmental_protection/Documents/ecoairports/Final\%20Airport\%20Eco\%20Desig n\%20Overview.pdf

13. Wijnen, R. A., Walker, E. W. and Kwakkel, H. J. (2008). Decision support for airport strategic planning. Transportation Planning and Technology, 31(1), pp. 11-34 